\title{
Efek Pemberian Ekstrak Etanol Buah Adas (Foenicullum vulgare Mill.) terhadap Kadar Hormon Prolaktin Tikus Putih Betina Post Partum
}

\section{The Effect of Ethanol Extract of Fennel Fruit (Foenicullum vulgare Mill.) on Hormone Prolactin Levels of White Female Post Partum Rats}

\author{
Ahwan Abdul", Fridah Wahyu Safitri, dan Rantika Purbowati \\ Program Studi Farmasi, Fakultas Sains, Teknologi dan Kesehatan, Universitas Sahid Surakarta, Solo, Indonesia \\ *Email: ahone.far02@gmail.com
}

Received: 14 November 2019; Accepted: 7 Juni 2020; Published: 22 Juni 2020

\begin{abstract}
Abstrak
Tanaman adas adalah tanaman yang mempunyai khasiat bermacam - macam secara tradisional, diantaranya sebagai pelancar Air Susu Ibu (ASI) atau laktagogum. Penelitian ini memiliki tujuan dari pemberian ekstrak etanol buah adas untuk menaikkan kadar hormon prolaktin pada tikus menyusui, sehingga ASI yang dihasilkan meningkat. Subyek terdiri dari 12 tikus betina post partum, dibagi menjadi 1 kelompok kontrol (CMC Na 1\%) dan 3 kelompok perlakuan (dosis 100, 500 dan $1000 \mathrm{mg} / \mathrm{Kg} \mathrm{BB}$ ). Ekstrak buah adas diberikan tiap kelompok secara oral selama 14 hari, setelah perlakuan sampel darah diambil dan disentrifugasi, serum dibaca dengan Elisa Reader. Data yang didapat dianalisis menggunakan uji Kolmogorov-Smirnov, one-way ANAVA dan Tukey's Multiple Comparison (post hoc test). Ekstrak buah adas yang diberikan dari dosis 100; 500 dan $1000 \mathrm{mg} / \mathrm{Kg} \mathrm{BB}$ dapat menaikkan kadar hormon prolaktin yang signifikan ( $\mathrm{p}<$ 0,05 ) pada tikus menyusui berturut-turut sebesar 42,$11 ; 44,26$ dan $43,83 \mathrm{ng} / \mathrm{mL}$ dibandingkan dengan kontrol $(32,64 \mathrm{ng} / \mathrm{mL})$.
\end{abstract}

Kata Kunci: ASI, hormon prolaktin, buah adas (Foenicullum vulgare mill) dan Elisa Reader

\begin{abstract}
Fennel plants are plants that have various traditional properties, such as facilitating breast milk or lactagogum. The aim of this research was to give ethanol extract of fennel fruit to increase the level of the hormone prolactin in lactating mice, so that the milk produced was increased. Subjects consisted of 12 postpartum female rats, divided into 1 control group (1\% CMC Na) and 3 treatment groups (doses of 100, 500 and $1000 \mathrm{mg} / \mathrm{Kg} \mathrm{BW}$ ). Fennel fruit extract was given orally for each group for 14 days, after the treatment of blood samples were taken and centrifuged, the serum was read by Elisa Reader. The data obtained were analyzed using the Kolmogorov-Smirnov test, one-way ANAVA and Tukey's Multiple Comparison (post hoc test). Fennel fruit extract given from a dose of 100; 500 and $1000 \mathrm{mg} / \mathrm{kg} \mathrm{BW}$ can significantly increase levels of the hormone prolactin ( $p<0.05$ ) in nursing mice, respectively by $42.11 ; 44.26$ and $43.83 \mathrm{ng} / \mathrm{mL}$ compared to controls (32.64 $\mathrm{ng} / \mathrm{mL})$.
\end{abstract}

Keywords: prolactin hormone, fruit fennel (Foenicullum vulgare mill) and Elisa Reader

\section{PENDAHULUAN}

Tanaman Adas (Foeniculum vulgare Mill) adalah tanaman dari keluarga umbelliferae. Tanaman ini tumbuh di daerah sub tropis dan dibudidayakan di wilayah mediterania dan eropa selatan. Diantaranya Pakistan, India, Amerika, Jerman dan Italia. Tanaman ini tumbuh di tanah kering, sinar matahari yang cukup dengan $\mathrm{pH}$ sekitar 5,56,5. Negara india dan Pakistan merupakan 
pemasok utama internasional tanaman adas (Javed et al., 2020).

Pemanfaatannya secara tradisional sebagai penghilang rasa nyeri, mengurangi peradangan, melancarkan sirkulasi peredaran darah, karminatif, menambah nafsu makan, mengobati penyakit lambung, cacingan (Mulyani et al., 2017). serta meningkatkan produksi Air Susu Ibu (ASI) (Badgujar et al., 2014).

ASI dihasilkan oleh proses rangsangan sistem saraf dan hormon secara mekanik. Hormon estrogen yang dapat mempengaruhi proses tersebut, hormon ini merupakan hormone seks yang dihasilkan oleh rahim melalui rangsangan pertumbuhan organ seks yang mengatur siklus menstruasi seperti pada kelenjar payudara dan rambut pubik. Proses kehamilan dapat menyebabkan kelenjar payudara semakin berkembang oleh pengaruh hormon estrogen, somatomammotropin dan prolaktin. Hormon estrogen dan progesteron menyebabkan hipertropi pada sistem ductus sehingga bertambahnya sel-sel asinus di kelenjar payudara menyebabkan pembentukan senyawa kasein, laktoglobulin dan laktoalbumin. Hormon prolaktin tidak dapat terbentuk waktu terjadi kehamilan dikarenakan terjadi penghambatan oleh Prolactin Inhibiting Hormone (PIH) (Septadina and Murti, 2018).

Pemberian ASI berdasarkan data Kementrian Kesehatan Republik Indonesia dari tahun 2014 - 2016. Pada tahun 2014 pemberian ASI seluruh Indonesia sebesar 52,3\% dan pada tahun 2015 menjadi 55,7\% terjadi peningkatan pemberian ASI tetapi tidak mencapai target $80 \%$. Sedangkan pada tahun 2016 sebesar 54,0 \% menyebabkan terjadi penurunan dari 2015 (Kementrian Kesehatan Republik Indonesia, 2017). Penurunan pemberian ASI secara nasional menjadi perhatian pemerintah dalam meningkatkan pemberian ASI oleh ibu menyusui. Hormon prolaktin ini adalah hormon yang dapat meningkatkan produksi ASI selain hormone lainnya. (Nurjanah et al., 2017).
Penggunaan obat tradisional oleh berbagai lapisan masyarakat yang semakin meningkat penggunaannya dengan adanya bukti ilmiah tentang keamanan dan manfaat tanaman obat yang digunakan sebagai obat tradisional (Ardiyanto, 2011). Sehingga obat tradisional dalam penggunaannya menjadi pilihan terapi dari pasien, dibandingkan obat kimia. Salah satu tanaman yang mempunyai khasiat sebagai laktagogum adalah tanaman adas (Badgujar et al., 2014). Pengunaan tanaman adas baik bagian daun, batang, dan buah/biji dari Foniculum vulgare, banyak digunakan sebagai laktagogum dan tidak hanya untuk meningkatkan kuantitas dan kualitas susu tetapi juga untuk meningkatkan aliran ASI ibu menyusui (Badgujar et al., 2014).

Pemberiaan sediaan infusa dan ekstrak etanol daun adas pada tikus putih mempunyai perbedaan signifikan pada pertumbuhan badan dan panjang tubuh anak tikus (Yana, 2017), sedangkan penggunaan biji adas dapat meningkatkan produksi susu pada kambing (Hamad and Hassbo, 2018). Peningkatan produksi ASI dipengaruhi oleh kandungan senyawa yang terdapat didalam tanaman adas yaitu flavonoid, fenolik, steroid dan komponen minyak atsiri (Barros et al., 2010).

Dari uraian diatas maka dapat dilakukan penelitian tentang pengaruh pemberian ekstrak buah adas terhadap kenaikan kadar hormon prolaktin pada tikus menyusui dan melakukan skrining fitokimia senyawa metabolit sekunder.

\section{METODE PENELITIAN \\ Alat dan Bahan}

Alat untuk penelitian ini: maserator, Rotary Evaporator, alat-alat gelas, waterbatch, spuit injeksi 3 dan $5 \mathrm{cc}$, sonde vacuum tube, ependorf, well 96, sentrifuge, Elisa Reader (Biotek), dan inkubator (Memmert).

Bahan untuk penelitian ini: simplisia buah adas, etanol $96 \%$, kertas saring, tikus putih betina galur Wistar, hormone prolactin rat kit elisa reader, $\mathrm{CMC} \mathrm{Na}$ dan akuades. 
Pembuatan Ekstrak Etanol Daun Adas.

Simplisia buah adas kering dihaluskan hingga sesuai partikel yang diinginkan sebesar $0,8 \mathrm{~kg}$, simplisia tersebut dimasukkan ke dalam maserator serta direndam dengan etanol $96 \%$ (1:5) sambil diaduk setiap 1 jam lalu didiamkan selama 24 jam. Maserat yang sudah disaring dengan corong buchner, diuapkan dengan menggunakan rotary evaporator dan waterbath dengan suhu $60^{\circ} \mathrm{C}$ sampai konsistensi kental. Selanjutnya dilakukan remaserasi sebanyak 3 kali.

\section{Skrining Fitokimia}

Identifikasi alkaloid. Ekstrak kental 100 mg dipanaskan dalam tabung $10 \mathrm{~mL}$ dengan menambahkan $\mathrm{HCl} 1 \%$ (7-8 mL) selama 30 menit dalam waterbatch. Bagian cairan diperoleh dengan cara menyaring. Destilat dibagi setengahnya dalam volume yang sama, tabung A dan B. Tabung A dibagi menjadi dua, larutan A-1 ditambahkan 3 tetes Dragendorff dan larutan A-2 ditambahkan dengan 3 tetes pereaksi Meyer.

Identifikasi flavonoid. Larutan uji: ekstrak kental sebesar 100 mg dipanaskan di dalam $10 \mathrm{~mL}$ metanol selama 10 menit pada waterbath. Hasil pemanasan disaring dalam keadaan panas dan diencerkan dengan akuades $10 \mathrm{~mL}$ hingga dingin, ditambahkan sebanyak $5 \mathrm{ml}$ wash benzene, dikocok dan dibiarkan selama beberapa menit dalam rak tabung reaksi, didapatkan dua lapisan. Lapisan atas (metanol) diuapkan dan residunya dilarutkan dalam $5 \mathrm{ml}$ etil asetat. Uji Taubeck: larutan uji $1 \mathrm{~mL}$ diuapkan dan residu dibasahi dengan aseton dan ditambahkan serbuk asam borat dan asam oksalat, dipanaskan dengan hati-hati dalam water bath. Hasil residu yang diperoleh ditambahkan $2 \mathrm{~mL}$ eter. dan dilihat di bawah sinar UV $366 \mathrm{~nm}$.

Identifikasi polifenol. Ekstrak kental sebanyak $100 \mathrm{mg}$ dilarutkan dalam $10 \mathrm{ml}$ air dan dipanaskan 10 menit dalam waterbatch. Hasil disaring dan diamkan dalam keadaan dingin, tiga tetes $\mathrm{FeCl}_{3}$ di tambahkan. Apabila terjadi perubahan warna menjadi hijau menunjukkan polifenol.
Identifikasi saponin. Sebanyak $100 \mathrm{mg}$ ekstrak kental ditambah $10 \mathrm{ml}$ air dan dipanaskan selama 5 menit, Hasil disaring dan dimasukkan ke tabung reaksi, dikocok kuat selama 10 detik dan didiamkan selama 10 menit. Hasil yang didapatkan berupa busa yang apabila ditambahkan 1 tetes $\mathrm{HCl} 1 \%$ membuat busa menjadi stabil, maka termasuk senyawa saponin.

Identifikasi tanin. Ekstrak kental sebanyak $100 \mathrm{mg}$ ditambah $10 \mathrm{ml}$ air dan dididihkan selama 14 menit, setelah dingin larutan tersebut disaring. Filtrat yang didapatkan dibagi menjadi dua bagian. Filtrat pertama ditambahkan $\mathrm{FeCl}_{3} 1 \%$, apabila tejadi perubahan warna menjadi biru tua atau hijau tua terdapat senyawa tannin.

Identifikasi antraquinon. $100 \mathrm{mg}$ ekstrak kental direbus selama 2 menit dengan penambahan $\mathrm{KCl} 0,5 \mathrm{~N}(10 \mathrm{~mL})$ dan $\mathrm{H}_{2} \mathrm{O}_{2}(1$ $\mathrm{mL}$ ). Pada suhu kamar larutan disaring. $5 \mathrm{~mL}$ filtrat ditambahkan dengan asam asetat (10 tetes) sampai $\mathrm{pH} 5$ ditambahkan toluena 10 $\mathrm{mL}$. Fase/bagian atas $(5 \mathrm{~mL})$ dipisahkan bagian bawah dengan menggunakan pipet dalam reaksi tabung. Ditambahkan beberapa tetes $\mathrm{H}_{2} \mathrm{O}_{2} \quad 0,5 \mathrm{~N}$ apabila terbentuk warna merah pada lapisan air (dasar) diindikasikan adanya antrakuinon.

Identifikasi terpenoid dan steroid. Dimaserasi sebesar $100 \mathrm{mg}$ ekstrak kental dalam $10 \mathrm{~mL}$ eter selama 2 jam, disaring dan diambil filtratnya. Filtrat diuapkan sebanyak $5 \mathrm{ml}$, residu yang diperoleh ditambah 2 tetes asam asetat anhidrat dan 1 tetes asam sulfat pekat. Apabila terjadi perubahan warna menjadi merah atau hijau menunjukkan adanya senyawa steroid/triterpenoid (Malik et al., 2016).

\section{Persiapan hewan uji}

Tikus putih betina galur wistar adalah hewan uji yang digunakan, tikus tersebut dalam kondisi hamil tua (berat badan: 200400 gram, masa kehamilan 1 minggu) hingga melahirkan (post partum).

\section{Pemberian ekstrak etanol daun adas}

Hewan uji tikus dibagi 4 kelompok (tiap kelompok: 3 hewan uji) yaitu kelompok I 
Tabel 1. Rendemen ekstrak etanol buah adas

\begin{tabular}{ccccc}
\hline No & Nama Simplisia & Berat Serbuk $(\mathrm{kg})$ & Berat Ekstrak $(\mathrm{kg})$ & Rendemen $(\%)$ \\
\hline 1 & Buah Adas & 0,8038 & 0,0394 & 4,91 \\
\hline
\end{tabular}

dengan dosis (CMC Na $1 \%)$, II (100 mg/Kg $\mathrm{BB})$, III (500 mg/Kg BB) dan IV (1000 $\mathrm{mg} / \mathrm{Kg} \mathrm{BB})$. Kelompok I merupakan kontrol pelarut dan kelompok II, III dan IV sebagai kelompok perlakuan. Setiap kelompok perlakuan diberikan secara oral (2,5 $\mathrm{mL} / 200 \mathrm{gBB}$ ) setiap hari selama 14 hari.

Pengambilan sampel darah

Tikus setelah diberi perlakuan selama 14 hari, darahnya diambil pada bagian sinus orbitalis. Darah dimasukkan ke vacuum tube, dipisahkan protein dan plasma dengan disentrifugasi $10000 \mathrm{rpm}$ selama 10 menit. Plasma yang diperoleh disimpan didalam freezer $\left(-4^{\circ} \mathrm{C}\right)$.

\section{Pengukuran kadar hormon prolaktin dengan metode Elisa Reader}

Plasma yang diperoleh dimasukkan kedalam well kit hormone prolactin elisa kit dan ditambahkan reagen kit elisa lalu diinkubasi selama 30 menit lalu dibaca dengan elisa reader diperoleh data absorbansi sampel dan standar baku hormon prolaktin.

\section{Analisa Data}

Data berat badan tikus (200-400 gram) dan kadar hormon prolaktin diuji distribusi normal dengan menggunakan kolmogorov smirnov. Kadar hormon prolaktin dhitung dengan menggunakan persamaan regresi linear $\mathrm{y}=\mathrm{bx}+\mathrm{a}$ dan dilanjutkan dengan diuji menggunakan One-Way ANOVA tiap kelompok perlakuan dengan dibandingkan dengan kontrol CMC Na $1 \%$.

\section{HASIL DAN PEMBAHASAN}

Simplisia buah adas yang sudah melalui tahapan sortasi diekstraksi menggunakan metode maserasi, maserat diuapkan menggunakan rotary evaporator dan diperoleh ekstrak kental etanol buah adas yang mempunyai ciri secara organoleptis yaitu ekstrak berwarna hijau, rasa agak pahit dan bau aromatis. Ekstrak tersebut dilakukan perhitungan rendemennya dari berat simplisia kering yang dimaserasi dan didapatkan berat rendemen pada tabel dibawah ini

Hasil rendemen ekstrak etanol buah adas pada tabel 1 sebesar $4,91 \%$, rendemen ini terbilang sedikit jumlahnya disebabkan oleh bagian tanaman, pelarut ekstraksi dan ukuran partikel buah adas yang digunakan (Ismail et al., 2012).

Skrining fitokimia dilakukan terhadap ekstrak buah adas dapat dilihat pada Tabel 2 .

Tabel 2. Skrining Fitokimia Ekstrak Etanol Buah Adas

\begin{tabular}{llc}
\hline No. & Senyawa & Hasil \\
\hline 1. & Alkaloid & ++ \\
2. & Flavonoid & ++ \\
3. & Polifenol & ++ \\
4. & Saponin & ++ \\
5. & Tanin & ++ \\
6. & Antraquinon & - \\
7 & Steroid & ++ \\
\hline
\end{tabular}

Keterangan: (+): Positif; (++): Sangat positif dan (-): negatif

Hasil skrining ekstrak buah adas menunjukkan bahwa ekstrak tersebut mengandung senyawa alkaloid, flavonoid, polifenol, saponin, steroid dan tannin. Secara teoritis tanaman buah adas mengandung minyak atsiri (terpenoid), flavonoid (polifenol), alkaloid, tannin dan steroid (stigmasterol) (Javed et al., 2020). Faktor yang mempengaruhi kandungan senyawa tersebut tempat tumbuh, waktu panen, identitas tanaman, bagian tanaman yang digunakan (Kusbiantoro and Purwaningrum, 2018).

Pada Tabel 3. dilakukan uji keseragaman data pada analisis data sampel berupa berat badan tikus setelah melahirkan dan kadar hormon prolaktin. Metode yang digunakan untuk mengetahui normalitas data salah satunya dengan menggunakan Kolmogorov- 
Tabel 3. Uji Distribusi Normal Sampel

\begin{tabular}{llccc}
\hline No. & \multicolumn{1}{c}{ Data Sampel } & Rata-rata & SD & Kolmogorof $S Z$ \\
\hline 1 & Berat Badan Tikus & 236,33 gram & $\pm 49,27$ & $0,749^{*}$ \\
2 & Kadar Prolaktin & $40,59 \mathrm{ng} / \mathrm{mL}$ & $\pm 5,54$ & $0,816^{*}$ \\
\hline & Keterangan: ${ }^{*}=$ Nilai $p>0,05$ tidak ada perbedaan bermakna dari data sampel
\end{tabular}

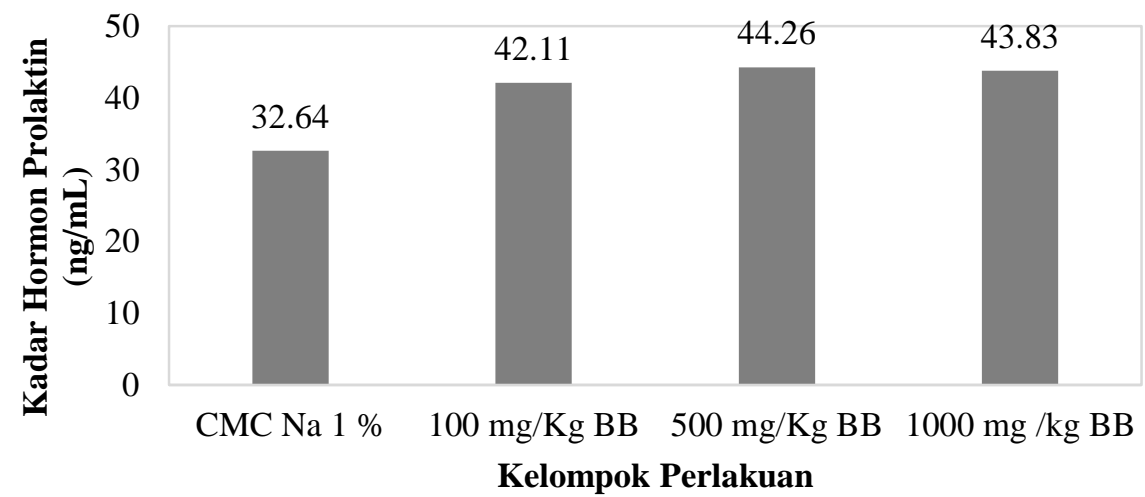

Gambar 1. Kadar Hormon Prolaktin Ekstrak Etanol Buah Adas

Smirnov (Oktaviani and Notobroto, 2014). Dari hasil pada tabel 3 data berat badan dan kadar hormon prolaktin tikus didapatkan terdistribusi normal, sehingga data tersebut dapat digunakan untuk uji One-Way Anova.

Pemberian ekstrak buah adas pada tikus betina post partum sebesar $100 ; 500$ dan 1000 $\mathrm{mg} / \mathrm{Kg}$ BB pada hari ke 3 sampai hari ke 14 dibandingkan kontrol CMC Na 1\%, diperoleh data kadar hormon prolaktin pada tikus betina pada Gambar 1.

Pemberian dosis ekstrak buah adas yang diberikan berturut-turut dengan dosis: 100, 500 dan $1000 \mathrm{mg} / \mathrm{Kg} \mathrm{BB}$, dapat dilihat pada Tabel 4. dapat menaikkan kadar hormon prolakin secara berturut-turut sebesar 42,11; 44,26 dan 43,83 ng/mL dibandingkan dengan kontrol (32,64 ng/mL). Apabila dibandingkan perlakuan dengan kontrol terdapat pengaruh yang signifikan pada pemberian ekstrak etanol buah adas. Penelitian ini diperkuat dimana penggunaan biji atau buah adas dapat menaikkan produksi ASI ibu menyusui dengan dosis yang tinggi dan penggunaan yang lama (Patel and Gedam, 2013). Penelitian pada bagian daun adas dapat meningkatkan berat badan anak tikus dimana indukan diberikan perlakuan ekstrak etanol daun adas (Yana, 2017). pada penggunaan minyak atsiri dari buah adas yang digunakan sebagai minyak urut pada ibu yang sedang menyusui dapat meningkatkan kadar hormon prolaktin (Raras et al., 2016).

Tabel 4. Kadar Hormon Prolaktin Ekstrak Etanol Buah Adas

\begin{tabular}{llcc}
\hline \multicolumn{1}{c}{ Kelompok } & N & $\begin{array}{c}\text { Kadar Hormon Prolaktin }(\mathrm{ng} / \mathrm{mL}) \\
\text { Mean } \pm \mathrm{SD}\end{array}$ & ANOVA \\
\hline Kontrol & 3 & $32,64 \pm 0,531$ & \\
$100 \mathrm{mg} / \mathrm{Kg} \mathrm{BB}$ & 3 & $42,11 \pm 3,437$ & $0,002^{*}$ \\
$500 \mathrm{mg} / \mathrm{Kg} \mathrm{BB}$ & 3 & $44,26 \pm 2,748$ & \\
$1000 \mathrm{mg} / \mathrm{Kg} \mathrm{BB}$ & 3 & $43,83 \pm 1,685$ & \\
\hline
\end{tabular}

Keterangan: * Terdapat perbedaan yang bermakna (p< 0.05); Kontrol (Lar. B (Ekstrak Buah Adas); Dosis $100 \mathrm{mg} / \mathrm{Kg}$ BB; Dosis 500 mg/Kg BB dan Dosis 1000 mg/Kg BB. 
Tabel 5.Perbandingan Perlakuan Tiap Dosis Ekstrak Etanol Buah Adas (Uji Post hoc tukey)

\begin{tabular}{lcccc}
\hline \multicolumn{1}{c}{ Buah Adas } & \multicolumn{4}{c}{ Perlakuan } \\
\cline { 2 - 5 } & Kontrol & $100 \mathrm{mg} / \mathrm{Kg} \mathrm{BB}$ & $500 \mathrm{mg} / \mathrm{Kg} \mathrm{BB}$ & $1000 \mathrm{mg} / \mathrm{Kg}$ BB \\
\hline Kontrol & - & $0,01^{*}$ & $0,003^{*}$ & - \\
$100 \mathrm{mg} / \mathrm{Kg} \mathrm{BB}$ & $0,010^{*}$ & - & 0,694 & $0,010^{*}$ \\
$500 \mathrm{mg} / \mathrm{Kg} \mathrm{BB}$ & $0,003^{*}$ & 0,694 & - & $0,003^{*}$ \\
$1000 \mathrm{mg} / \mathrm{Kg} \mathrm{BB}$ & $0,003^{*}$ & 0,811 & 0,996 & $0,003^{*}$ \\
\hline \multicolumn{2}{c}{ Keterangan: * Terdapat perbedaan yang bermakna $(\mathrm{p}<0.05)$}
\end{tabular}

Kombinasi senyawa alkaloid dan saponin yang terdapat pada ekstrak buah adas dapat meningkatkan produksi hormon prolaktin melalui proses penghambatan dopamin, sehingga hormon prolaktin yang berfungsi mensintesis ASI di sel sekretorius alveoli. Senyawa saponin dapat menaikkan aktivitas hormon oksitosin di sel mioepitel pada bagian alveoli dan duktus. Alkaloid berfungsi sebagai agonis reseptor $\alpha$-adrenergik di duktus kelenjar mamma, memiliki mekanisme mesinergiskan hormon oksitosin saat terjadinya sekresi ASI (Kharisma et al., 2011). Selain senyawa alkaloid dan saponin, senyawa flavonoid dan polifenol mempunyai sifat estrogenik sehingga dapat merangsang produksi hormon oksitosin dan prolaktin (Suksesty, 2017)

Dosis pemberian ektrak buah adas yang paling berpengaruh untuk kenaikan kadar hormon prolaktin pada dosis pemberian 100 $\mathrm{mg} / \mathrm{Kg}$ BB (Tabel 5). Dosis yang berpengaruh dalam meningkatkan pertumbuhan anakan tikus sebesar 631,6 $\mathrm{mg} / \mathrm{Kg} \mathrm{BB}$ tetapi pada ekstrak daun adas (Rifqiyati et al., 2018). sedangkan pada daun katuk yang sudah terbukti secara praklinis dapat menaikkan kadar hormon prolaktin tikus menyusui sebesar $72 \mathrm{mg} / \mathrm{Kg}$ BB (Miharti et al., 2018). Hasil tersebut hanya berbeda sedikit dengan ekstrak buah adas yang dapat menaikkan kadar hormon prolaktin pada dosis $100 \mathrm{mg} / \mathrm{Kg} \mathrm{BB}$.

\section{KESIMPULAN}

Kandungan senyawa metabolit sekunder didalam ekstrak buah adas yaitu alkaloid, flavonoid, polifenol, saponin, tannin dan steroid. Pemberian ekstrak buah adas kepada tikus menyusui memberikan efek yang signifikan terhadap kadar hormon proklatin dengan dosis efektif sebesar $100 \mathrm{mg} / \mathrm{Kg} \mathrm{BB}$ dibandingkan dengan kontrol.

\section{Daftar Pustaka}

Ardiyanto, D., 2011. Observasi Klinik Jamu Sebagai Dasar Ilmiah Terapi Kedokteran Moderen., Solo, in: Paper Presented at the Simposium Penelitian Bahan Obat Alami XV. Surakarta.

Badgujar, S.B., Patel, V. V., Bandivdekar, A.H., 2014. Foeniculum vulgare Mill: A review of its botany, phytochemistry, pharmacology, contemporary application, and toxicology. Biomed Res. Int. 2014, 1-32. https://doi.org/10.1155/2014/842674

Barros, L., Carvalho, A.M., Ferreira, I.C.F.R., 2010. The nutritional composition of fennel (Foeniculum vulgare): Shoots, leaves, stems and inflorescences. LWT - Food Sci. Technol. 43, 814-818. https://doi.org/10.1016/j.lwt.2010.01.010 
Hamad, M.E., Hassbo, R.M., 2018. Effect of some antioxidants on productive and reproductive performance of Damascus goats during late pregnancy and lactation stages. Egypt. J. Sheep Goat Sci. 13, 37-47.

Ismail, J., Runtuwene, M.R.., Fatimah, F., 2012. Penentuan Total Fenolik dan Uji Aktivitas Antioksidan pada Biji dan Kulit Buah Pinang Yaki (Areca vestiaria Giseke). J. Ilm. SAINS 12, 84. https://doi.org/10.35799/jis.12.2.2012.557

Javed, R., Hanif, M.A., Ayub, M.A., Rehman, R., 2020. Fennel, in: Muhammad Hanif, Haq Nawaz, Muhammad Mumtaz Khan, H.J.B. (Ed.), Medicinal Plants of South Asia. Elsevier, Amsterdam, pp. 241-256. https://doi.org/10.1016/B978-0-08-102659-5.00019-7

Kementrian Kesehatan Republik Indonesia, 2017. Data dan Informasi Profil Kesehatan Indonesia Tahun 2016. Jakarta.

Kharisma, Y., Ariyoga, A., Sastramihardja, H.S., 2011. Efek Ekstrak Air Buah Pepaya (Carica papaya L.) Muda terhadap Gambaran Histologi Kelenjar Mamma Mencit Laktasi. Maj. Kedokt. Bandung 43, 160-165. https://doi.org/10.15395/mkb.v43n4.63

Kusbiantoro, D., Purwaningrum, Y., 2018. Pemanfaatan kandungan metabolit sekunder pada tanaman kunyit dalam mendukung peningkatan pendapatan masyarakat. Kultivasi 17, 544-549. https://doi.org/10.24198/kultivasi.v17i1.15669

Malik, A., Edward, F., Waris, R., 2016. Skrining Fitokimia dan Penetapan Kandungan Flavonoid Total Esktrak Metanolik Herba Boroco (Celosia argentea L.). J. Fitofarmaka Indones. 1, 1-5. https://doi.org/10.33096/jffi.v1i1.193

Miharti, S.I., Oenzil, F., Syarif, I., 2018. Pengaruh Pemberian Ekstrak Etanol Daun Sauropus Androgynus (L). MERR (Katuk) terhadap Kadar Hormon Prolaktin pada Tikus Putih (Wistar Albino Menyusui). J. Ipteks Terap. 202. https://doi.org/10.22216/jit.2018.v12i3.3806

Mulyani, H., W, S.H., E, V.I., 2017. Pengobatan Tradisional Jawa Dalam Manuskrip Serat Primbon Jampi Jawi. LITERA 16, 139-151. https://doi.org/10.21831/ltr.v16i1.14257

Nurjanah, S., Kamariyah, N., Soleha, U., 2017. Pengaruh Konsumsi Ekstrak Daun Sauropus androgynus (L) Meer (Katu) Dengan Peningkatan Hormon Prolaktin Ibu Menyusui Dan Perkembangan Bayi Di Kelurahan Wonokromo Surabaya. J. Heal. Sci. 10, 24-35.

Oktaviani, M.A., Notobroto, H.B., 2014. Perbandingan tingkat konsistensi normalitas distribusi metode kolmogorov-smirnov, lilliefors, shapiro-wilk, dan skewness-kurtosis. J. Biometrika dan Kependud. 3, 127-135.

Patel, U., Gedam, D.S., 2013. Effect of back massage on lactation among postnatal mothers. Int. J. Med. Res. Rev. 1, 5-13. https://doi.org/https://doi.org/10.17511/ijmrr.2013.i01.02

Raras, N.S., Suwondo, A., Wahyuni, S., Laska, Y., 2016. Different Amount of Prolactin Hormone Before and After Acupressure-aromatherapy Combination Technique in 
Lactation: Epidemiological-clinic Study on Post Partum Mother in Surakarta District Hospital, in: ASEAN/Asian Academic Society International Conference Proceeding Series. Nakhon Pathom, pp. 332-338.

Rifqiyati, N., Sulistiyawati, S., Sunaini, S., 2018. Pengaruh Ekstrak Ethanol Daun Adas (Foeniculum vulgare Mill.) pada Induk Tikus (Rattus norvegicus) Masa Laktasi Terhadap Pertumbuhan Anak. Integr. Lab J. 4, 199-206.

Septadina, I.S., Murti, K., 2018. Effects of Moringa Leaf Extract (Moringaoleifera) in the Breastfeeding. Sriwij. J. Med. 1, 74-79. https://doi.org/10.32539/SJM.v1i1.10

Suksesty, C.E., 2017. Pengaruh jus campuran kacang hijau terhadap peningkatan hormon prolaktin dan berat badan bayi. J. Ilm. Bidan 2, 32-40.

Yana, Y.D., 2017. Efektifitas Infusa Daun Adas (Foeniculum vulgare L.) pada Tikus Putih (Rattus sp.) Pasca Melahirkan Terhadap Pertumbuhan Anakan'. Yogyakarta Univ. Islam Negeri Sunan Kalijaga. Universitas Islam Negeri Sunan Kalijaga. 